\title{
The Shamans of Wall Street: A Real Conundrum in Finance. Why Systematically Poor Performing Asset Managers Survive?
}

\section{Los chamanes de Wall Street: un real acertijo en finanzas. ¿Por qué sistemáticamente gerentes de inversiones incompetentes sobreviven?}

\author{
Francisco A. Delgado 1 \\ Diego C. Cueto ${ }^{2}$
}

Received: November 13, 2011

Accepted: February 02, 2012 Man is a rational animal-so at least I have been told. Throughout a long life, I have looked
diligently for evidence in favor of this statement, but so far I have not had the good fortune
to come across it, though I have searched in many countries spread over three continents.
On the contrary, I have seen the world plunging continually further into madness.

Bertrand Russell

(1) Men would never be superstitious, if they could govern all their circumstances by set rules, or if they were always favored by fortune: but being frequently driven into straits where rules are useless, and being often kept fluctuating pitiably between hope and fear by the uncertainty of fortune's greedily coveted favors, they are consequently, for the most part

very prone to credulity.

(2) The human mind is readily swayed this way or that in times of doubt, especially when hope and fear are struggling for the mastery, though usually it is boastful, over-confident, and vain.

Baruch de Spinoza

\begin{abstract}
In this paper we propose a behavioral explanation for the survival of poorly performing asset managers. We argue that, in general, asset managers make use of copious amounts of correct but useless information to convince investors about their supposed superior ability to interpret the market. Their marketing skills and motivational speeches seem to be enough to maintain asset managers in business regardless of the results. We present data that show how bad a number of asset managers can be. We also show how prevalent asset managers' underperformance is. We argue that some Wall Street professionals are able to fool almost all of their clients most of the time into believing that they add value in the services they provide while the data show that this is not true. What we cannot show with this data is whether managers actually believe they are as good as they claim they are, or are not just shamans, albeit shameless as well.
\end{abstract}

Keywords: Asset Management, Performance Evaluation, Behavioral Finance, Alpha, Emerging Market Equity.

1. Professor of Finance, Universidad ESAN. <fdelgado@esan.edu.pe>.

2. Assistant Professor, Universidad ESAN.<dcueto@esan.edu.pe>.

J. econ. finance adm. sci., 17(32), 2012 


\section{Resumen}

En este artículo proponemos una explicación conductual sobre la supervivencia de gerentes de inversiones incompetentes. Aquí argumentamos que, en general, los gerentes de inversiones hacen uso de voluminosas cantidades de correcta pero ineficaz información para convencer a sus inversores acerca de su supuesta superior habilidad para interpretar el mercado. Sus destrezas en marketing y discursos motivacionales parecen ser suficientes para mantener a los gerentes de inversiones dentro del negocio, sin tener en cuenta sus resultados. Aquí presentamos datos que muestran qué tan malos un número de gerentes de inversiones pueden ser. También mostramos cuán prevalentemente pobre es su rendimiento. Nosotros sostenemos que algunos de los profesionales de Wall Street son capaces de engañar a casi todos sus clientes la mayoría del tiempo haciéndoles creer que ellos le añaden valor a los servicios que les prestan, mientas que los datos señalan que no es verdad. Lo que no podemos demostrar con estos datos es si los gerentes realmente creen que ellos son buenos, o que solamente son unos chamanes, aunque descarados.

Palabras claves: Gerente de inversiones, evaluación de desempeño, conducta financiera, Alpha, acciones de mercados emergentes 


\section{INTRODUCTION}

This article presents what we consider a real conundrum in financial economics: the persistence of underperforming asset managers. We call it a real conundrum because it is not due to the difference between a theoretical model and market data as is the case in academic research as represented by the "equity premium puzzle" (Mehra \& Prescott, 1985). What we report is the resulting conflict between behavior/data and simple common sense precepts. In simple terms, when financial economic models forecasts are rejected by the data, scientists not tied to their models would at least initially consider the possibility that their models are wrong. Behavioral economics has given us plenty of evidence (Akerlof \& Yellen, 1985; Barberis \& Thaler, 2003; Hirshleifer, 2001; Rubinstein, 2001) that individuals are not fully rational even when making monetary decisions. We also know we cannot use common sense to forecast human behavior. Some people may choose less than optimal outputs as long as they feel they are relatively better than others.

The first part of the article shows that asset managers cannot really beat the market. The market is accepted to be efficient in its semi-strong form. Agents are assumed to be fully rational; however, on average, asset managers do worse than the market net of transactions costs. Traditionally, asset manager performance is compared against the market returns in a single factor model. This kind of comparison or performance evaluation may be insufficient and the benchmark may be inadequate. Our analysis involves comparing the performance of most of the asset managers specialized in emerging markets equity against a relevant Exchange Traded Fund (ETF) ${ }^{1}$ as benchmark. One would expect that professional investors choose among the best performing asset managers in the same asset class; with the highest return for a given level of

1 The best way to describe what ETF is to compare it to a mutual fund. ETF is just like an actively managed mutual fund but without the expense and complication of managers and management fees. Additionally, they can be traded at any time without any fees or loads from the management company. volatility. Our main research questions can be stated as follows: 1) why would any individual or institutional investor choose a systematically underperforming asset manager? Alternatively, 2) why do poor performing asset managers survive for long periods of time? Answering these questions would explain the existence of underperforming managers because we would expect the market to clear itself removing poorly performing asset managers.

If we knew why underperforming managers continue to be chosen by investors, then we would obtain the reason why underperforming managers continue in business. This line of research does not allow anonymity: poor performing managers have to be analyzed individually so as to point out their poor performance. In some categories the average manager might marginally do better than the benchmark, but many individual managers will do poorly. We need to show individual poor performing managers.

The second part of the article suggests a simple hypothesis that may explain these poor performing managers' survival, as well as why lack of performance is not enough to convince people of the futility of the enterprise. Both individual and professional clients first intuitively assign "intention" to the market and then grant credibility to asset managers that promise that their information and skills are enough to explain and forecast market movements, something that the ex-post data show they cannot do. "Intention" is the level of explanation needed to understand a phenomenon. Dennett (2006) defines three levels of explanation: a) physical; b) design, and c) intentional. For instance, objects fall due to physical reasons: gravity [a]; cars move because of their design [b]; and humans knock at doors because they want them opened: intentional [c].

As humans, we often assign intentional sources to inanimate objects; for instance in classical periods, we used to believe that thunder was caused by angry gods and so on. Dawkins (2009) advances a possible explanation for religious convictions: intentional stance in humans coupled with the need for explaining complex phenomena opens up humans to exploitation by religious "shamans". Borrowing from Dawkins' position, we argue that some Wall Street professionals act as religious shamans would do: they pretend to understand, 
explain and forecast markets and companies. The copious amounts of correct and detailed information about markets and companies that asset managers possess and convey may convince their audiences that they can actually do better than the market. These financial professionals convince their clients that they can identify the "intentions" of the market and their information and experience is what is needed to understand the market. Indeed, religious shamans also pretend to understand the gods.

\section{ASSET MANAGERS DATA AND ANALYSIS APPROACH}

The standard academic approach of using the CAPM (Capital Asset Pricing Model) or the market model provides misleading results when used carelessly. The performance of managers is best measured against a benchmark for the asset class the manager invests in and not assuming a globally diversified portfolio. Furthermore, our analysis concentrates on a clean asset class. The assertion of the existence of a "clean" class demands further explanation. In the global economy, Emerging Markets equities as a class have performed better than $\mathrm{EAFE}^{2}$ and US equities (see Figure 1). These results give incentives to asset managers to "drift" outside their classes. As an example of this phenomenon, we can consider American Funds Growth Fund of America A (AGTHX), whose portfolio includes, as of May 2010, 17\% in international stocks (EAFE). This fund is sold as US equities of large companies that pay smaller dividends and the stated benchmark is the S\&P500 index. Consider also American Funds Euro Pacific Gr A (AEPGX) whose portfolio also contains about $20 \%$ in emerging markets stocks, as of May 2010, even though it is billed as a developed market international fund. At the beginning of 2010, Morningstar named AEPGX as the best international fund. By including assets from classes that have performed

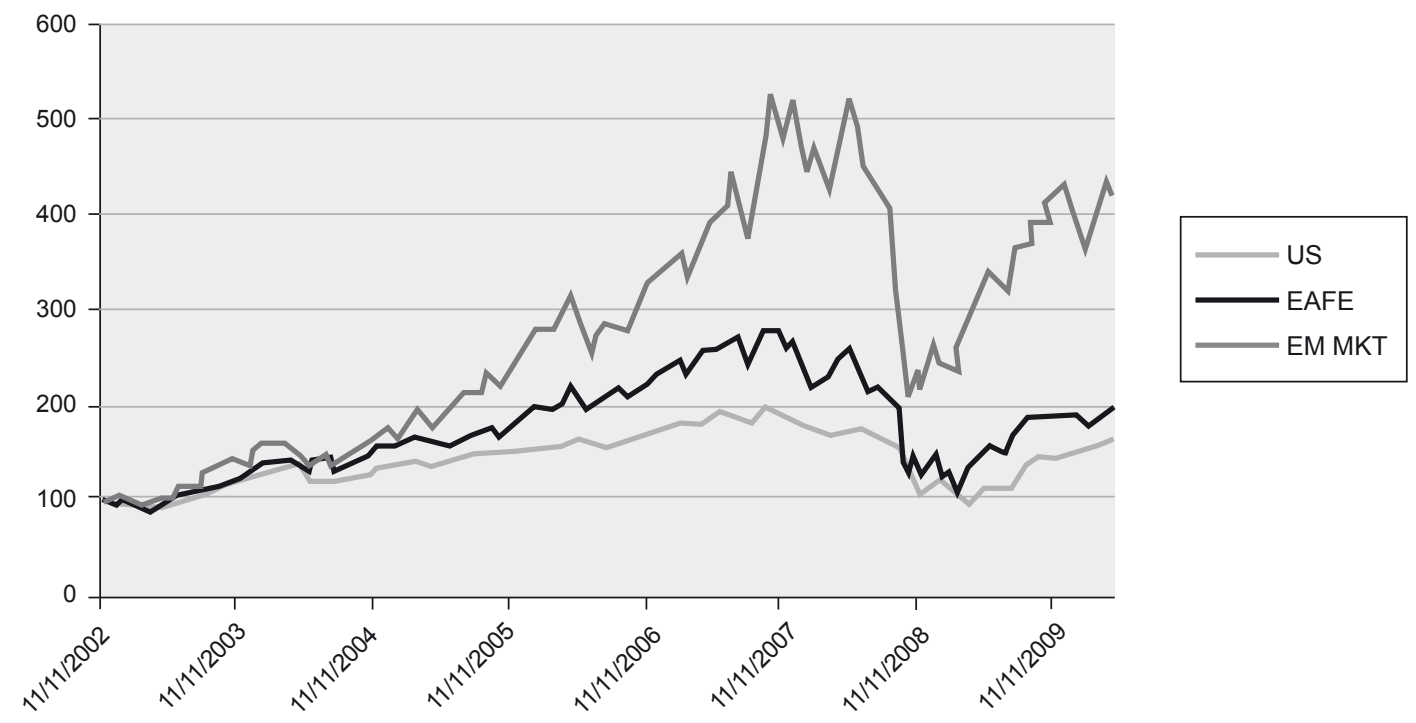

Source: Morningstar

Figure 1. Relative performance of three equity asset classes: US equity, EAFA equity, and Emerging Market equity.

2 EAFE, which stands for Europe, Australia, and the Far East, represents equities in developed countries excluding Canada. 
better in their portfolios, managers are able to report better performance than their reported benchmarks.

It is not unusual for asset managers to invest outside their class; it is actually the norm in the industry, not the exception. However, this drift slightly complicates the analysis for most equity managers because of the need to adjust for this non-constant drift. Typically, a two stage procedure could be used to perform the analysis. The idea would be to orthogonalize the two asset classes by using the residuals of the regression of one on the other in the regression with the portfolio manager. This approach is unnecessary with a clean asset class.

Emerging Market fund managers, unlike other managers, do not drift outside their class. In Emerging Markets funds, as an asset class, this drift has not taken place, precisely because of its high performance. There is no incentive for asset managers to drift into developed equity and none is observed. Consequently, we have the rare opportunity to observe a clean asset class and we consider a sample of the best Emerging Market Equity funds in the analysis. Emerging Markets represent the fastest growing economies in the world. They include what Goldman Sachs branded the BRIC's (Brazil, Russia, India, and China). They also include Mexico, Indonesia, Greece, and Korea, among many others. Our sample consist on 19 five stars funds and 24 four and three stars funds, the best funds according to Morningstar ${ }^{3}$ that specialize in emerging markets equities.

We collected weekly prices from data published from 2002 to 2010 . We have carefully chosen a high performance ETF as benchmark for the study and a risk free-asset (SHY). Figure 2 shows that, for the common sample in both categories, there are funds that consistently underperform the benchmark ETF ADRE4, which is an asset that can be purchased in any account,

3 An alternative to Morningstar rankings would be Lipper which uses an index of the performance of asset managers in that category as a benchmark. Morningstar uses EAFE, the developed world index, as the benchmark for Emerging Market performance comparisons.

4 DEM, another ETF, has a shorter history, and, therefore, was not chosen for the study. It could have been used for the smaller samples, but we would have lost the comparability between the two groups. takes into consideration all fees and commissions and still survive. Moreover, during the last economic crisis, some four and three stars funds even underperform the risk-free asset and they were not removed from the market. Performance is compute as the weekly returns normalized relative to the common initial period after a $5.75 \%$ total commission and fees are deducted. Conversely, the emerging market index (EM MKT in Figure 1) is structured without taking into account real world factors such as transactions costs and could therefore be considered an unfair comparison benchmark.

For each fund separately, we regress the excess return over the risk-free asset (SHY) on the excess rerun of the benchmark using the following model: $R-R_{f}=\alpha+\beta\left(R_{m}-R_{f}\right)+\varepsilon$. In Table 1 we report the average return, standard deviation, beta and alpha, for the common period from May 2007 to April 2010. Over longer common periods the sample of managers shrinks because not all funds have been in existence, but the results are similar to those shown and they are available from the authors upon request.

We report that in several asset classes there are managers that consistently underperform but continue in business. In Table 1 we observe that most asset managers with five stars obtain negative alpha over the three years period that included the financial crisis. After accounting for transaction cost, these asset managers are unable to beat the benchmark ETF. Theoretically, this failure should be enough for them to leave the asset management market.

Table 2 shows the results for asset managers with four and three stars. Alphas are even more negative over the period for almost all the funds. These asset managers claim that their competitive advantage over the ETF is to actively manage the portfolio. The evidence shown here suggests that they do not possess or deliver those supposed superior skills. Sound investors would not trust their capital to an asset manager that charges fees and commissions and is unable to beat the ETF, which is also available for trading. We also observe that it is precisely during crisis periods that managers do worse than the ETF.

To check robustness, we calculated alpha over rolling windows of 250 weeks from September 2007 to April 2010, to discard that our results are an artifact of the 

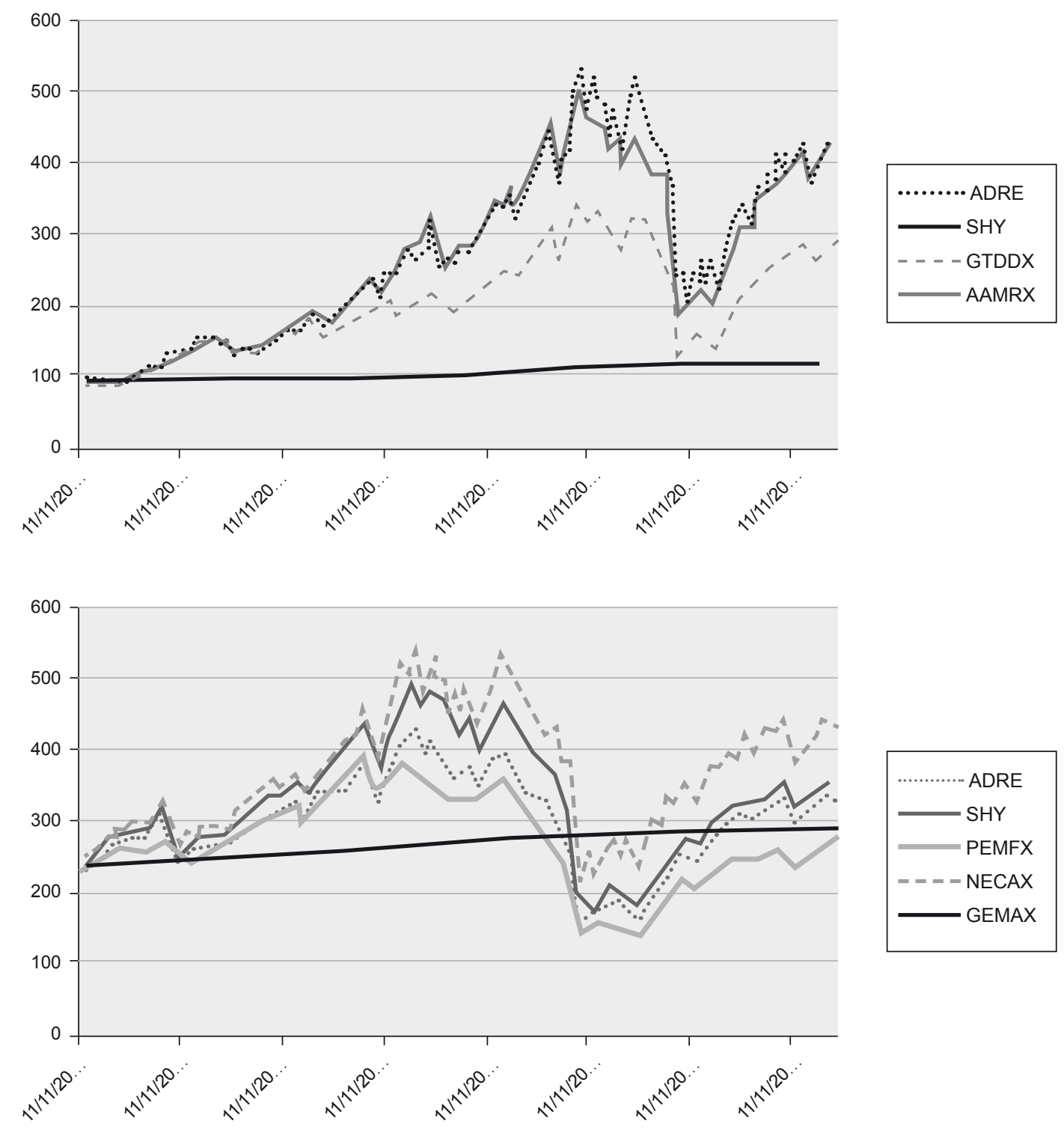

Source: Morningstar

Figure 2.

Panel A. Performance of selected five stars emerging market asset managers compared against ADRE, the best Emerging Market ETF and SHY.SHY is the ETF that we use as the risk free asset, it invests in US treasuries with maturities of about 12 months. The sample extends from November 2002 to May 2010.

Panel B. Performance of selected four and three starsemerging market mutual funds compared against ADRE, the best Emerging Market ETF and SHY. SHY is the ETF that we use as the risk free asset, it invests in US treasuries with maturities of about 12 months. The sample extends from November 2005 to May 2010. 
Table 1.

Five stars funds specialized in Emerging Markets equities.

\begin{tabular}{|c|c|c|c|c|c|c|}
\hline & & & Average & Standard & & \\
\hline Ticker & Name & Size & Return & Deviation & Beta & Alpha \\
\hline SNEMX & Bernstein Emerging Market & 2034 & -0.06 & 0.37 & 0.97 & $-3.28 \%$ \\
\hline PIEIX & Principal Intl Emerging Markets & 1447 & -0.06 & 0.35 & 0.97 & $-3.06 \%$ \\
\hline NEWFX & American Funds New World & 17481 & -0.05 & 0.28 & 0.96 & $-2.11 \%$ \\
\hline HEMZX & Virtus Emerging Markets Opportuniti A & 326 & -0.05 & 0.29 & 0.95 & $-2.08 \%$ \\
\hline HLEMX & Harding Loevner Emerging & 1780 & -0.04 & 0.36 & 0.97 & $-1.86 \%$ \\
\hline DREGX & Driehaus Emerging Markets & 596 & -0.04 & 0.33 & 0.96 & $-1.83 \%$ \\
\hline EAEMX & Eaton Vance Structured Em & 1374 & -0.04 & 0.31 & 0.95 & $-1.58 \%$ \\
\hline RSRIX & Threadneedle Emerging Markets I & 655 & -0.04 & 0.36 & 0.97 & $-1.22 \%$ \\
\hline AAMRX & American Beacon Emerging & 142 & -0.04 & 0.33 & 0.97 & $-1.22 \%$ \\
\hline GTDDX & AIM Developing Markets & 1411 & -0.04 & 0.29 & 0.95 & $-1.17 \%$ \\
\hline DFEMX & DFA Emerging Markets I & 3281 & -0.03 & 0.33 & 0.97 & $-0.55 \%$ \\
\hline MEMKX & BNY Mellon Emerging Marke & 1793 & -0.03 & 0.33 & 0.96 & $-0.26 \%$ \\
\hline JFAMX & JPMorgan Emerging Mkts Eq & 1073 & -0.03 & 0.34 & 0.97 & $-0.20 \%$ \\
\hline DRFMX & Dreyfus Emerging Markets & 959 & -0.02 & 0.32 & 0.95 & $0.35 \%$ \\
\hline LZOEX & Lazard Emerging Markets E & 14384 & -0.02 & 0.33 & 0.95 & $0.70 \%$ \\
\hline GBEMX & RS Emerging Markets & 1835 & -0.01 & 0.37 & 0.97 & $1.20 \%$ \\
\hline EMGAX & Evergreen Emerging Market & 967 & -0.01 & 0.32 & 0.98 & $1.23 \%$ \\
\hline DEMAX & Delaware Emerging Markets & 896 & -0.01 & 0.35 & 0.96 & $1.50 \%$ \\
\hline ODMAX & Oppenheimer Developing Ma & 12984 & 0.01 & 0.33 & 0.96 & $3.80 \%$ \\
\hline
\end{tabular}

Source: Morningstar

period of analysis. Figure 3 shows decreasing alpha, diving into negative grounds during the crisis period to never entirely recover, whereas other assets have already emerged from the red.

\section{RESULTS AND INVESTOR BELIEFS}

In simple terms, the question is this: why any investor, let alone an institutional investor, would select an asset manager that has consistently underperformed the benchmark ETF ADRE? Investors could simply choose the ETF. This represents an enigma for most of the funds in Table 1 and Table 2. A similar question we need to answer is why individuals and institutional investors do not choose the better performing ETF benchmark. Corporate investors are professionals for whom this selection ought to be quite simple. We argue that asset manager undertake marketing activities to convince their clients that they can help understanding, explaining, and forecasting markets. Asset managers either explicitly or intuitively suppress rational thinking to set credibility for what is not rationally credible. Incidentally, many spiritual tenets are held against evidence and are billed as faith. Basically, spiritual people believe against evidence. These mental modules may have evolved 
Table 2.

Four and Three Stars Funds Specialized in Emerging Markets Equities.

\begin{tabular}{|c|c|c|c|c|c|}
\hline & & Average & Standard & & \\
\hline Ticker & Name & Return & Deviation & Beta & Alpha \\
\hline UUPIX & ProFunds UltraEmerging Markets Inv & -0.26 & 0.78 & 0.99 & $-23.10 \%$ \\
\hline GEMFX & U.S. Global Investors Glbl Emerging Mkts & -0.19 & 0.36 & 0.03 & $-18.90 \%$ \\
\hline NECAX & ING Emerging Countries A & -0.14 & 0.33 & 0.96 & $-11.99 \%$ \\
\hline NECIX & ING Emerging Countries I & -0.14 & 0.33 & 0.95 & $-11.56 \%$ \\
\hline AOTAX & Allianz NACM Emerging Markets Opp A & -0.13 & 0.37 & 0.96 & $-10.57 \%$ \\
\hline ETEMX & Eaton Vance Emerging Markets A & -0.11 & 0.34 & 0.97 & $-8.46 \%$ \\
\hline GEGAX & Aberdeen Emerging Markets A & -0.10 & 0.35 & 0.94 & $-8.03 \%$ \\
\hline AEMMX & American Century Emerging Markets A & -0.10 & 0.35 & 0.96 & $-7.46 \%$ \\
\hline DAEMX & Dunham Emerging Markets Stock A & -0.09 & 0.32 & 0.90 & $-7.08 \%$ \\
\hline AOTIX & Allianz NACM Emerging Mkt Opp I & -0.09 & 0.36 & 0.96 & $-6.85 \%$ \\
\hline WBEIX & William Blair Emerging Mkts Growth I & -0.07 & 0.36 & -0.06 & $-6.69 \%$ \\
\hline PEMFX & Pioneer Emerging Markets A & -0.09 & 0.38 & 0.97 & $-6.26 \%$ \\
\hline FEMKX & Fidelity Emerging Markets & -0.08 & 0.37 & 0.97 & $-6.01 \%$ \\
\hline MSRIX & Van Kampen Emerging Markets I & -0.05 & 0.35 & 0.01 & $-5.23 \%$ \\
\hline FAMKX & Fidelity Advisor Emerging Markets A & -0.07 & 0.37 & 0.97 & $-4.85 \%$ \\
\hline AEMGX & Acadian Emerging Markets & -0.06 & 0.37 & 0.96 & $-3.76 \%$ \\
\hline PRMSX & T. Rowe Price Emerging Markets Stock & -0.06 & 0.36 & 0.96 & $-3.74 \%$ \\
\hline GEMAX & Goldman Sachs Emerging Mkts Equity A & -0.06 & 0.36 & 0.97 & $-3.65 \%$ \\
\hline ARTEX & Artisan Emerging Markets Inst & -0.05 & 0.35 & 0.96 & $-2.45 \%$ \\
\hline PWEAX & UBS PACE International Em Mkts Eq A & -0.05 & 0.35 & 0.97 & $-2.18 \%$ \\
\hline TABRX & Templeton BRIC A & -0.04 & 0.40 & 0.95 & $-1.94 \%$ \\
\hline AAEPX & American Beacon Emerging Mkts Inv & -0.04 & 0.32 & 0.97 & $-1.76 \%$ \\
\hline TEMMX & Templeton Emerging Markets Small Cap A & -0.01 & 0.29 & -0.07 & $-1.46 \%$ \\
\hline EMGAX & Wells Fargo Advantage Emerg Mkt Eq A & -0.01 & 0.32 & 0.97 & $1.88 \%$ \\
\hline
\end{tabular}

Source: Morningstar

from religion and they are now used to sustain beliefs against evidence in financial markets.

There are two requirements for this to hold:

1. Intentional Stance (Dennett, 2006) proposes that people give human-like intentions to nonhuman actors. People talk about the market be- ing on edge, or optimistic or pessimistic or many other human characteristics. One only needs to listen to financial journalists to see how pervasive this attitude is. Basically, many market participants treat implicitly the market as an entity with intentions, not a purely random process. They therefore look for explanations in terms 

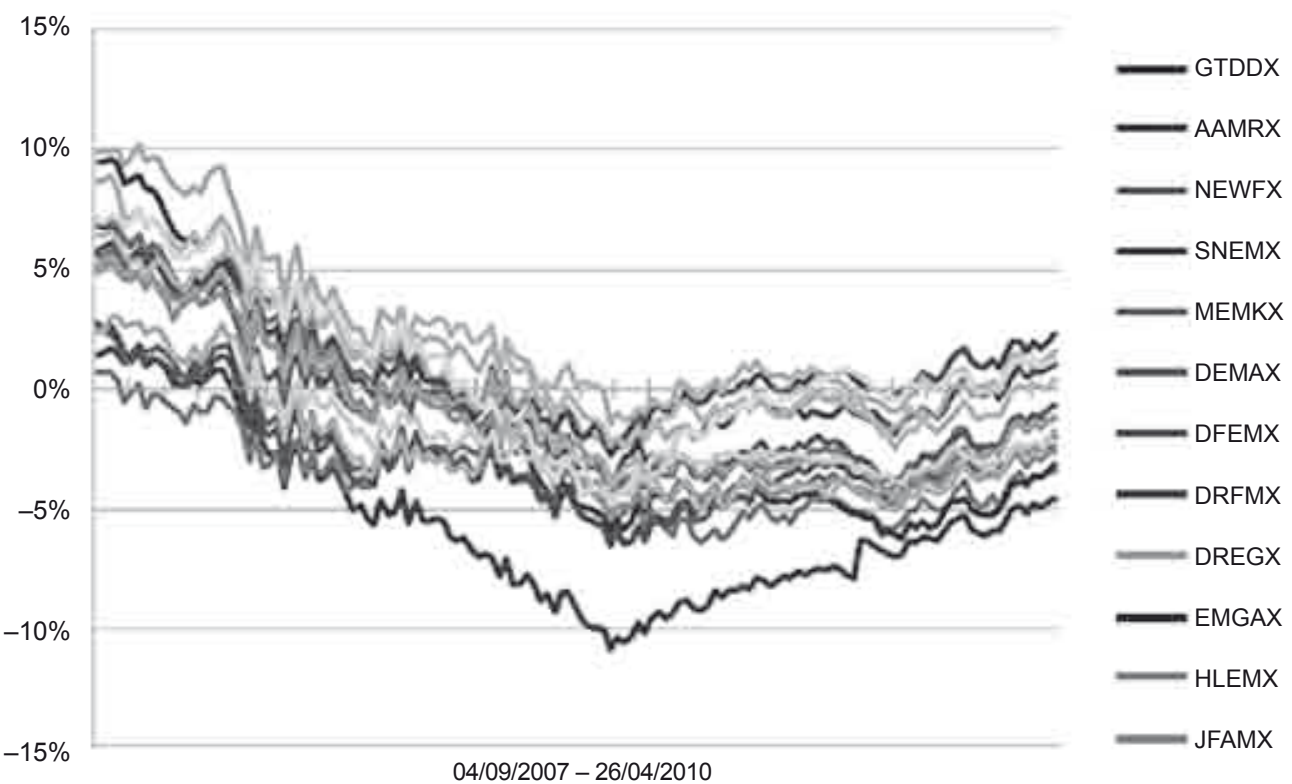

Source: Morningstar

Figure 3. Panel A: Rolling alpha, 250 weeks window, 5 stars funds

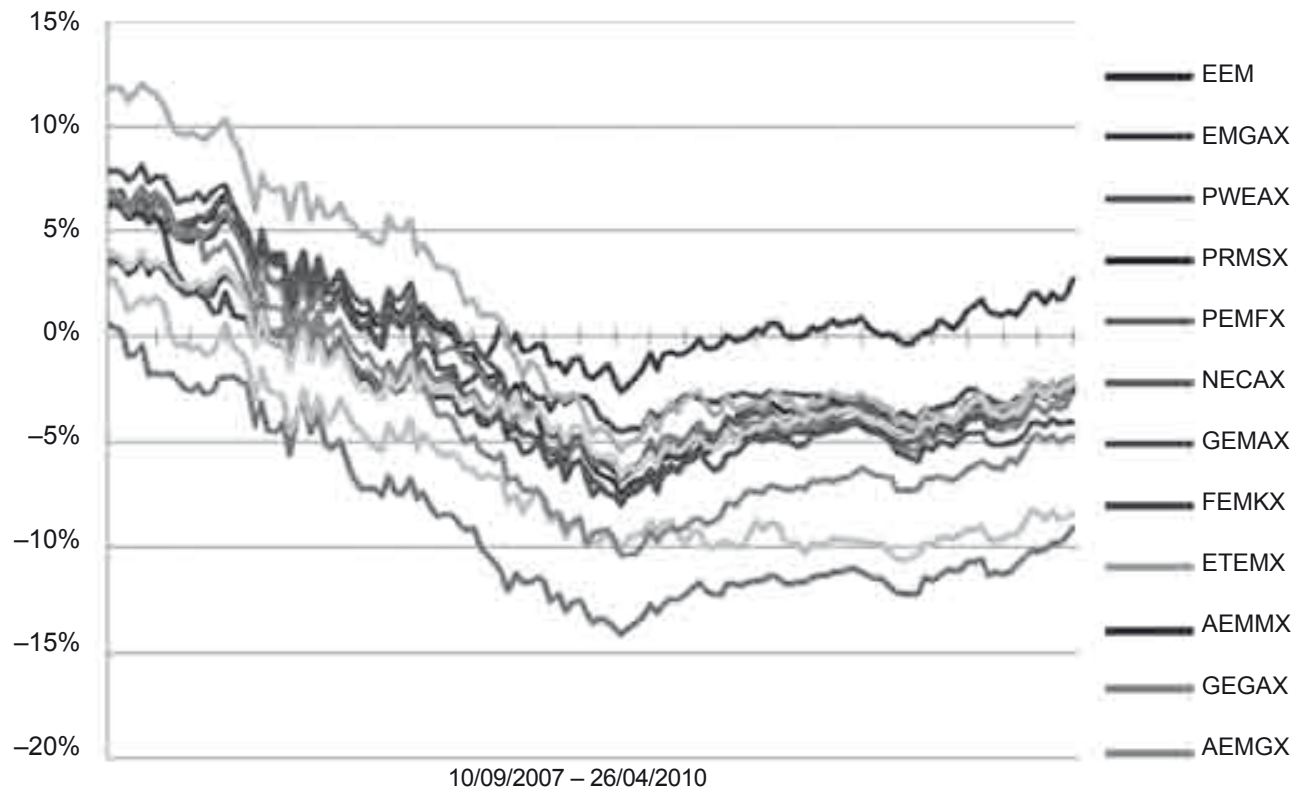

Source: Morningstar

Figure 3. Panel B: Rolling Alpha, 250 weeks window, 4,3 stars funds 
of intentions. Very little evidence is needed to argue that the market is down because of this or that event. These statements cannot be proved, but many people often make them and others believe them if heard constantly.

2. There is the need to explain the random evolution of market variables. One of the most common questions asked about a result in the market is why the market went up today; or, why the stock went down last week. These are questions that look for an answer beyond the obvious "because the market is random".

The combination of these two features of human psychology produces beliefs that allow describing, explaining, and forecasting the companies or markets to anyone with some understanding of certain details and little information, but not superior forecasting skills. The job of market specialists is therefore to forecast the intentions of the market by carefully studying the past as well as current conditions. People conclude that someone with this amount of information must add value to the process of investing.

\section{CONCLUDING REMARKS}

It is impossible to fit the results of systematic and long term poor asset manager performance within the standard rational expectations framework of academic theory. Therefore, it is imperative to look for an explanation within a behavioral framework. We show that most asset managers in the class of Emerging Market equity have underperformed the ETF benchmark since their inception. Nevertheless, these asset managers not only survive but they thrive against all odds. We proposed that a hypothesis used to explain people's willingness to believe may be used to explain this unusual behavior. The results found analyzing Emerging Market equity managers can be extended to other classes of asset managers. These results point clearly to a regulatory framework where asset manager report their results along those of the ETF benchmark in the same asset class. This will allow both individual as well as corporate investors to determine simply and directly how good their asset managers are.

\section{References}

Akerlof, G., \& Yellen, J. (1985). Can Small Deviations from Rationality Make Significant Differences to Economic Equilibria? American Economic Review, 75(4), 708-720

Barberis, N., \& Thaler, R.(2003). A Survey of Behavioral Finance. In G. M. Constantinides, M. Harris \& R. M. Stulz (Eds.) Handbook of the Economics of Finance. The Netherlands: North Holland.

Dawkins, R. (2009). The Greatest Show on Earth: The Evidence for Evolution. New York: Free Press.
Dennett, D. (2006). Breaking the Spell: Religion as a Natural Phenomenon. New York: Viking Press

Hirshleifer, D. (2001). Investor Psychology and Asset Pricing. Journal of Finance, 56(4), 1533-1597.

Mehra, R., \& Prescott, E. (1985).The Equity Premium: A Puzzle. Journal of Monetary Economics, 15,145-16.

Rubinstein, M. (2001). Rational Markets: Yes or No? The Affirmative Case. Financial Analysis Journal, 57(3), 15-29. 